\title{
Preparation and Sensory Evaluation of Arrowroot Masala Khakhra
}

\author{
Meenu Aggarwal, Priyanka Verma and Dipti Sharma* \\ Department of Food Technology, Shyama Prasad Mukherji College for Women (SPM College), University of Delhi, India \\ *Corresponding author: sharmadipti23@gmail.com
}

Received: $19-07-2018$

Revised: $24-10-2018$

Accepted: 28-11-2018

\begin{abstract}
Khakhra is a crispy version of roti, it is usually a cracker that is handmade and roasted to provide crunchiness. It is also a healthy snack which is a common recipe in the Rajasthani and Gujarati cuisines of western India, especially a Jain's and Gujarati's. In present investigation efforts were made to prepare masala khakhra by using different proportions of ingredients like whole wheat, besan, rice flour, arrowroot powder, dehydrated onion. After few trials a recipe was standardized using blends of whole wheat flour, gram flour, rice flour, arrowroot powder, dehydrated onion and spices to taste. Physico-chemical, nutritional profile and sensory analysis of final product made using standardized recipe was carried out. Sensory evaluation was done by semi trained panelists on 5 point hedonic scale. Shelf-life study of the final product was carried over a period of 14 days at room temperature it was found that product maintained the required texture for first seven days at room temperature.
\end{abstract}

Keywords: Masala khakhra, Sensory Evaluation, Traditional Recipe, Nutritional value, Rice flour, Arrowroot powder, Dehydrated onion

Khakhra is a traditional ready-to-eat snack or breakfast item popular in the North Western part of India. This product is very popular in the state of Gujarat. As a convenient snack it is popular during travels because it does not require any further processing at the point of consumption, need minimal packaging and has long shelf-life. Khakhra is a nutritious Indian diet snack. Very crispy, crunchy, mouthwatering tasty and very light in weight snack. Favorite among people of all ages from children \& teenagers to adult. Available in many different flavors. It is usually relished with various kinds of chutneys, pickles, with coffee, tea, butter, ghee, topped vegetable, cheese or yoghurt. It is easy to carry and most of the people carry these as snack during travel. Since, khakhra is very simple to make and is enjoyed as a food item, its value addition can be done by adding many healthy ingredients in powered form as it is to be rolled very thinly. Value addition of khakhra with healthy flours, and/or with seeds like garden cress seeds, linseeds etc. will provide novel health benefits and this is the gap in the market as these supplemented and enriched khakhras as not available as such. These enriched khakhra's will further provide consumers a new alternative to traditional khakhras. More over this research will bring a new potential to the existing khakhra market. Today, we find that the people are becoming more aware about their health and various problems related to it. Thus, for maintaining changing life style and stay fit one needs to eat nutritious as well as healthy food.

This study aimed to develop masala khakhra by using blend of whole wheat flour ( $a$ tta), bengal gram flour (besan), rice flour, arrowroot powder and other spices 
to add taste to the khakhra. Role and nutritional importance of various ingredients used in preparation of khakhra are discussed below:

Whole wheat flour or atta is used instead of refined wheat flour or maida as it contains complex carbohydrates, dietary fiber, and a moderate amount of proteins. Wheat germ is the heart of the kernel, is particularly rich in vitamin. It is known to be the main source of the vitamin complex in dietary structures throughout the world and includes vitamins like thiamine, folic acid, vitamin B6, and minerals like manganese, magnesium, and zinc. Fiber improves gut health. Whole wheat flour will provide the basic structure along with the bengal gram flour.

Bengal gram flour or besan is rich in carbohydrates, protein, and fiber. It doesn't have gluten. This flour can be used for gluten free formulations with other ingredients. It is a great source of fiber; the flour can ease your digestive system. (Clemente et al. 1998). It is the source of protein in present work on khakhra to supplement the cereal/ whole wheat flour.

Arrowroot powder is used as a binding agent and to provide crispiness to khakhra, apart from its other hidden nutritional benefits. Arrowroot powder is used to help with weight loss, improve immunity, help reduce the risk of birth defects due to the presence of B Vitamin folate. It plays a significant role in improving the functioning of the heart, blood pressure and people suffering from hypertension can benefit from using arrowroot.

As such, milk is a wholesome food it has various minerals like calcium, phosphorus, magnesium, and potassium, protein and vitamins. The calcium found in milk is readily absorbed by the body (Choi BS et $a l$.$) , it is the source of calcium and other minerals in$ the khakhra.

Green chillis and onions were used to add the taste and variety. The high amounts of vitamin and capsaicin in green chillis are responsible for the health benefits that one receives from green chilli, it helps to boost metabolism and can help loose weight too. They can also fight inflammation, treat stomach illnesses, and keep your heart healthy. They're also believed to prevent cancer and delay its progression. Onion contains phosphorus, potassium, sulphur, and copper.

Spices not just excite one's taste buds but is also composed of an impressive list of phytonutrients, essentials oils, antioxidants, minerals and vitamins that are essential for overall wellness.

This study aims to develop masala khakhra using blends of whole wheat flour, besan, rice flour, arrowroot powder, dehydrated onion, milk, green chilli, red chili powder, kasuri methi, oil, celery, garam masala. Various combination of these ingredients were tried before concluding the standardized recipe. The product formulated from the standardized recipe were evaluated for product quality characteristics and shelf-life analysis. Five (5) point hedonic scale was used to evaluate the sensory characteristics of the product.

\section{MATERIALS AND METHODS}

Masala khakhra was made using blends of whole wheat, besan, rice flour, arrowroot powder, dehydrated onion, milk, green chilli, red chili powder, kasuri methi, oil, celery, garam masala. Following methodology was followed for developing masala khakhra:

\section{(i) Raw Material Procurement}

Raw materials like whole wheat flour, besan, rice flour, arrowroot powder, milk, edible oil, salt, and spices like red chili powder, turmeric powder, green chili, kasturi methi, cumin etc. were purchased from local market in Punjabi Bagh, Delhi, India.

\section{(ii) Preparing Control Sample of Masala Khakhra}

Control sample of khakhra was prepared using whole wheat flour (100 percent) with added spices, it is labelled as $\mathrm{T}_{0}$. Dough temperature was maintained at room temperature. Both control and trial doughs were formed as per the recipe mentioned in table 1.0.

\section{(iii) Preparing Flour Sample blend for Masala Khakhra}

Recipe of Masala khakhra was standardized using different trials by doing slight variations in the 
Table 1: Table showing methodology for various trials

\begin{tabular}{llllll}
\hline Trials $\rightarrow$ & $\mathbf{T}_{0}$ & $\mathbf{T}_{1}$ & $\mathbf{T}_{2}$ & $\mathbf{T}_{3}$ & $\mathbf{T}_{4}$ \\
\hline Ingredients $\downarrow$ & Amount & Amount & Amount & Amount & Amount \\
\hline Wheat Flour & $100 \mathrm{~g}$ & $50 \mathrm{~g}$ & $40 \mathrm{~g}$ & $30 \mathrm{~g}$ & $40 \mathrm{~g}$ \\
Rice Flour & 0 & $50 \mathrm{~g}$ & $30 \mathrm{~g}$ & $30 \mathrm{~g}$ & $30 \mathrm{~g}$ \\
Besan & 0 & 0 & $30 \mathrm{~g}$ & $30 \mathrm{~g}$ & $20 \mathrm{~g}$ \\
Arrowroot Powder & 0 & 0 & 0 & $10 \mathrm{~g}$ & $10 \mathrm{~g}$ \\
Onion & $10 \mathrm{~g}$ & $10 \mathrm{~g}$ & $10 \mathrm{~g}$ & $10 \mathrm{~g}$ & $10 \mathrm{~g}$ \\
Milk & $30 \mathrm{ml}$ & $30 \mathrm{ml}$ & $30 \mathrm{ml}$ & $30 \mathrm{ml}$ & $30 \mathrm{ml}$ \\
Green Chilli & 1 & 1 & 1 & 1 & 1 \\
Red Chilli Powder & $2 \mathrm{~T}$ & $2 \mathrm{~T}$ & $2 \mathrm{~T}$ & $2 \mathrm{~T}$ & $2 \mathrm{~T}$ \\
Kasturi Methi & $2 \mathrm{~T}$ & $2 \mathrm{~T}$ & $2 \mathrm{~T}$ & $2 \mathrm{~T}$ & $2 \mathrm{~T}$ \\
Oil & $2 \mathrm{~T}$ & $2 \mathrm{~T}$ & $2 \mathrm{~T}$ & $2 \mathrm{~T}$ & $2 \mathrm{~T}$ \\
Moringa leaves & $1 \mathrm{t}$ & $1 \mathrm{t}$ & $1 \mathrm{t}$ & $1 \mathrm{t}$ & $1 \mathrm{t}$ \\
Salt & $2 \mathrm{t}$ & $2 \mathrm{t}$ & $2 \mathrm{t}$ & $2 \mathrm{t}$ & $2 \mathrm{t}$ \\
Turmeric & $1 / 4 \mathrm{t}$ & $1 / 4 \mathrm{t}$ & $1 / 4 \mathrm{t}$ & $1 / 4 \mathrm{t}$ & $1 / 4 \mathrm{t}$ \\
Cumin & $1 / 2 \mathrm{t}$ & $1 / 2 \mathrm{t}$ & $1 / 2 \mathrm{t}$ & $1 / 2 \mathrm{t}$ & $1 / 2 \mathrm{t}$ \\
Asafoetida & 1 pinch & 1 pinch & 1 pinch & 1 pinch & 1 pinch \\
Garam Masala & $1 \mathrm{~T}$ & $1 \mathrm{~T}$ & $1 \mathrm{~T}$ & $1 \mathrm{~T}$ & $1 \mathrm{~T}$
\end{tabular}

quantity of wheat flour, rice flour, arrowroot powder and dehydrated onion. Dough temperature was maintained at room temperature. The dough was formed as per the methodology given in table 1. After developing each trial sample product sensory evaluation was carried out by 10 semi trained panelist to ascertain its consumer acceptability.

\section{Standardization of Recipe}

Recipe of Masala khakhra was standardized by performing different trials by bringing variations in the quantity of wheat flour, rice flour, arrowroot powder and dehydrated onion.

$\mathrm{T}_{0}$ was the control recipe in which only wheat flour was added, this was not good in protein and not even crispy so $\mathrm{T}_{1}$ recipe was made in which $50 \mathrm{~g}$ of wheat flour and $50 \mathrm{~g}$ of rice flour was added to increase crispiness but still khakhra was lacking in protein so to increase protein content $T_{2}$ recipe was made in which $40 \mathrm{~g}$ of wheat flour, $30 \mathrm{~g}$ of rice flour and $30 \mathrm{~g}$ besan was added but the khakhra became soggy and crispiness was gone completely to compensate the loss $\mathrm{T}_{3}$ recipe was tried in which $30 \mathrm{~g}$ of wheat flour, $30 \mathrm{~g}$ of rice flour, $30 \mathrm{~g}$ of besan and $10 \mathrm{~g}$ of arrowroot powder was added, but it was found that there was more of besan flour so another trial was done named $\mathrm{T}_{4}$ in which $40 \mathrm{~g}$ of wheat flour, $30 \mathrm{~g}$ of rice flour, $20 \mathrm{~g}$ of besan and $10 \mathrm{~g}$ of arrowroot powder was added which resulted in crispy and khakhra with enhanced protein value. T4 was the standardized khakhra recipe, the sample of which was analyzed for various physico-chemical analysis.

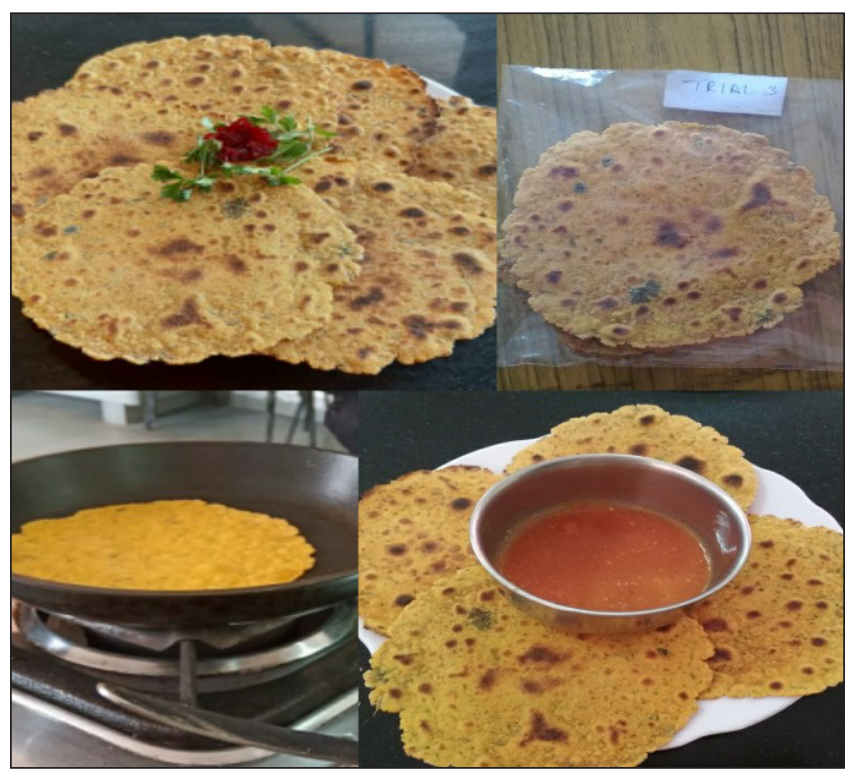

Fig. 1: Picture showing the developed standardized sample $\left(\mathrm{T}_{4}\right)$ 


\section{RESULTS AND DISCUSSION}

Results of various trials in terms of physico-chemical analysis are discussed below.

\section{(i) Sensory Evaluation}

Organoleptic characteristics are the most important properties of khakhra for its consumer acceptability Sensory evaluation of the Masala khakhra of sample $\mathrm{T}_{0} \mathrm{~T}_{1^{\prime}}, \mathrm{T}_{2}, \mathrm{~T}_{3^{\prime}}, \mathrm{T}_{4}$ was carried out on the basis of appearance, color, flavor, texture, taste, and overall acceptability with the help of sensory evaluation on hedonic scale by semi trained panelist of ten students of SPM college. The panelist were trained over a period of three months, the average scores given by panelist is shown in the table 2. It was observed that trial - 4 containing wheat flour, rice flour, besan and arrowroot powder was the most accepted recipe among all other trials.

Table 2: Table showing Sensory Evaluation of various trials

\begin{tabular}{lllccc}
\hline Parameter & Trial $\mathrm{T}_{0}$ & Trial $\mathrm{T}_{1}$ & Trial $\mathrm{T}_{2}$ & Trial $\mathrm{T}_{3}$ & Trial $\mathrm{T}_{4}$ \\
\hline Appearance & 3.5 & 3.0 & 3.0 & 4.0 & 5.0 \\
Color & 3.5 & 3.0 & 3.5 & 4.5 & 5.0 \\
Texture & 3.0 & 2.5 & 4.0 & 4.5 & 5.0 \\
Taste \& Flavor & 3.5 & 3.0 & 3.5 & 4.0 & 4.5 \\
Overall & 3.0 & 3.0 & 3.5 & 4.5 & 5.0 \\
Acceptability & & & & & \\
\hline
\end{tabular}

\section{(ii) Physical Properties of Khakhra}

The understanding of physical quality attributes is critical in designing end product and its use; different individual grains have different physical characteristics that may dictate end product quality and application (GM Solanke et al. 2018). Physical characteristics of the selected sample viz. diameter, thickness, and weight were studied. The results pertaining to physical properties of khakhra are presented in Table 3. It was recorded from Table 3 that the diameter of the khakhra was found to be 15.2 $\mathrm{cm}$ and the thickness was $2.65 \mathrm{~mm}$. The weight of the khakhra was found $15 \mathrm{gm}$. The results were similar to control sample.

Table 3: Table showing physical properties of $\mathrm{T}_{0}$ and $\mathrm{T}_{4}$

\begin{tabular}{lll}
\hline Parameter & $\mathrm{T}_{\mathbf{0}}{ }^{*}$ & $\mathbf{T}_{4}{ }^{*}$ \\
\hline Diameter $(\mathrm{cm})$ & 15.5 & 15.2 \\
Thickness (mm) & 2.5 & 2.65 \\
Weight $(\mathrm{gm})$ & 12 & 15 \\
\hline
\end{tabular}

${ }^{*}$ Each value is a mean of three determination.

\section{(iii) Nutritive Value}

Nutritional composition represents the nutritional quality of product. The nutritional composition of ingredients adds to the nutritional quality of final product. The data pertaining to nutritional composition of khakhra per $100 \mathrm{gm}$ is depicted in Table 4. From the nutritional analysis, it was found that trial khakhra was nutritionally better to control khakhra. The product comparatively better amount of iron and protein and was low in energy value.

Table 4: Table showing nutritive value of $\mathrm{T}_{0}$ and $\mathrm{T}_{4}$

\begin{tabular}{lll}
\hline Parameter & $\mathrm{T}_{\mathbf{0}}{ }^{*}$ & $\mathrm{~T}_{4}{ }^{*}$ \\
\hline Energy (KJ) & 2060 & 1978 \\
Fat $(\mathrm{g})$ & 33.46 & 34.17 \\
Protein (g) & 11.82 & 12.17 \\
Iron (mg) & 1.86 & 3.143 \\
Calcium (mg) & 69.34 & 62.29 \\
\hline
\end{tabular}

\section{(iv) Shelf-life Analysis}

Shelf-life is an important parameter of marketability, consumer acceptance of any food by a consumer. Shelflife study was done physically and microbiologically for 14 days at room temperature. From the results it is concluded that the product has shelf-life of 7 days at room temperature recorded in Delhi, India in the month of April. 
Table 5: Table showing shelf-life value of $\mathrm{T}_{4}$

\begin{tabular}{|c|c|c|}
\hline Days & Sensory Analysis & $\begin{array}{l}\text { Microbial } \\
\text { Analysis }\end{array}$ \\
\hline 0 Day & $\begin{array}{l}\text { Taste was good, appearance, } \\
\text { texture was good }\end{array}$ & $\begin{array}{l}\text { No Microbial } \\
\text { Activity } \\
\text { Observed }\end{array}$ \\
\hline 7 Day & $\begin{array}{l}\text { Taste was good, texture was well } \\
\text { maintained, color slightly reduced }\end{array}$ & $\begin{array}{l}\text { No Microbial } \\
\text { Activity } \\
\text { Observed }\end{array}$ \\
\hline $\begin{array}{l}14 \\
\text { Day }\end{array}$ & Texture was soft, and decolored & $\begin{array}{l}\text { Mold } \\
\text { Observed }\end{array}$ \\
\hline
\end{tabular}

\section{(v) Cost Analysis}

The raw materials were sourced locally, the cost of ingredients and overhead costs were added to calculate the total cost of product.

Table 6: Table showing the cost of $\mathrm{T}_{0} \& \mathrm{~T}_{4}$

\begin{tabular}{lll}
\hline & $\mathrm{T}_{0}{ }^{*}$ & $\mathrm{~T}_{4}{ }^{*}$ \\
\hline Cost/100g of flour taken & 20.00 & 32.00 \\
\hline
\end{tabular}

From cost analysis it is concluded that Total Cost of $\mathrm{T}_{0} \& \mathrm{~T}_{4}$ are $₹ 20 \& ₹ 32 \mathrm{~T}_{4}$ trial sample was costly as compared to control sample as different flours were used.

\section{(vi) Packaging and Labelling}

Packaging \& Labelling is an important part of a consumer's appeal for a product, especially with first time purchases. It is important to consider how consumers will view the packaging and if it will convey the product's quality goals, such as being a high-quality premium product. Primary packaging was done in polyethylene bags which will protect khakhra from moisture, spoilage of colour, flavour, odour, texture and will prevent from biological chemical or physical hazards, will control absorption of flavour and losses of oxygen and water vapour. Then it will be packed in an outer packet to protect its breakage and give strength during the transit. Final product was labelled properly according to FSSAI regulations in which all mandatory information like name of the product, list of ingredients, declaration regarding vegetarian food, net quantity, name and address of manufacturer batch no., date of manufacturing and best before date is mentioned on the package.

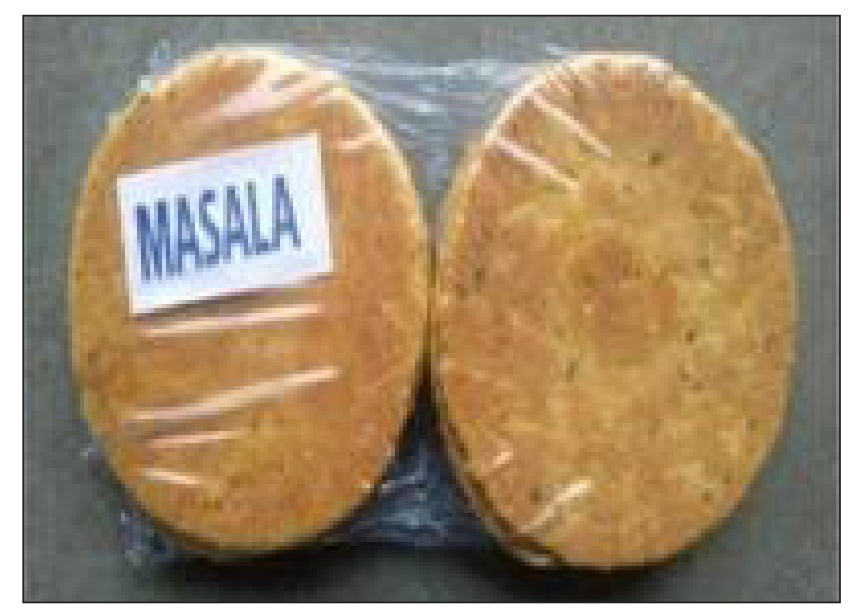

Fig. 2: Picture showing the packed $\mathrm{T}_{4}$ Sample

\section{CONCLUSION}

Better taste and superior nutritive value of khakhra justifies its high consumer acceptability. On the basis of results, it could be concluded that $\mathrm{T}_{4}$ recipe containing wheat flour, besan, rice flour and arrowroot is ideal for preparation of khakhra. After the preparation of value added khakhra it was packed in pouches. Then the physico-chemical properties were evaluated containing different various parameters. The shelf life study of the khakhra was carried out in the intervals of 0,7 , and 14 days the effect was checked during storage condition. Nutritional value of control and trial samples was checked and $T_{4}$ was found to be nutritionally better compared with control $\mathrm{T}_{0}$.

\section{ACKNOWLEDGMENTS}

Authors acknowledges the work done by students Ms. Beena and Ms. Yogeeta of Shyama Prasad Mukherji College for Women.

\section{REFERENCES}

AACC. 2003. Approved methods of the American Association of Cereal Chemists St. Paul, MN: American Association of Cereal Chemists. 
AOAC. 2005. Official Methods of Analysis. Association of official Analytical Chemistry, 16th ed. Washington DC, U.S.A.,

Clemente, A., Sánchez-Vioque, R., Vioque, J., Bautista, J. and Millán, F. 1998. Effect of cooking on protein quality of bengal gram (Cicer arietinum) seeds. Food Chemistry, 62(1): 1-6.

Choi, B.S. and Kim, H.Y. 2011. Quality of arrowroot dasik prepared with the arrowroot (Puerariae radix) powder. The Korean Journal of Culinary Research, 17: 197-207.
Solanke, G.M., Aditya Lal, Samarth, A.G., Annie Ankita Lal and Tiwari, P. 2018. Development and quality evaluation of value added Khakhra using different variety and proportion of flour. Journal of Pharmacognosy and Phytochemistry, 7(4): 1778-1781. 